\title{
Skrofuloderma pada Anak: Penyakit yang Terlupakan? Laporan Kasus
}

\author{
Johnny Nurman, Darmawan B. Setyanto \\ Departemen Ilmu Kesehatan Anak, RS Dr Cipto Mangunkusumo, Fakultas Kedokteran Universitas \\ Indonesia, Jakarta
}

\begin{abstract}
Skrofuloderma atau tuberkulosis kulit sering mengalami keterlambatan dalam diagnosis baik pada negara berkembang ataupun industri dewasa ini. Seorang anak perempuan umur 13 tahun 6 bulan dirujuk dengan keluhan utama pasca biopsi benjolan di leher dan ketiak kanan. Pasien menderita kelainan pada regio servikalis, submandibula dan aksila dekstra berupa benjolan sebesar telur puyuh, keras, tidak nyeri dan terfiksasi dan lesi plak eritematosa dengan pinggir kebiruan dan hiperpigmentasi berukuran $1 \times 1 \mathrm{~cm}$ sampai $5 \times 10 \mathrm{~cm}$, bentuk tidak teratur, tersusun linier, berbatas tegas. Benjolan dikeluhkan sejak 4 tahun yang lalu dan memburuk sesuai perjalanan waktu. Kuku jari tangan tampak berwarna kuning kecoklatan dan mengeras dengan permukaan yang tidak merata. Konsultasi kepada dokter telah dilakukan namun orang tua pasien tidak pernah dijelaskan mengenai penyakit yang diderita anaknya. Pengobatan dengan obat yang tidak jelas dan perawatan luka dilakukan pada setiap konsultasi. Riwayat tuberkulosis dalam keluarga disangkal namun tetangga pasien diketahui menderita batuk berdarah. Hasil uji Mantoux memperlihatkan bula berdiameter $>15 \mathrm{~mm}$, kemudian pecah dan menjadi lesi ulkus setelah 2 minggu. Hasil biopsi kulit menunjukkan seluruh dermis dipadati oleh sel radang terutama limfosit, sel plasma polimorphic multiple nucleous (PMN), dan tampak sel-sel epiteloid dan sel datia Langhans; juga daerah yang granulomatus. Kultur jaringan setelah 8 minggu, memperlihatkan hasil biakan positif Mycobacterium tuberculosis, apusan sedian langsung tidak ditemukan kuman tahan asam, tetapi uji niasin positif. Berdasarkan telaah dari anamnesis, pemeriksaan fisis dan penunjang, dapat disimpulkan diagnosis skrofuloderma, gizi kurang, perawakan pendek karena penyakit kronis, tersangka anemia defisiensi besi, dan onikomikosis. Pasien mendapat terapi obat anti tuberkulosis per oral dengan isoniazid $1 \times 200 \mathrm{mg} / \mathrm{hari}$ dan rifampisin $1 \times 300 \mathrm{mg} / \mathrm{hari}$ selama 6 bulan, pirazinamid 1 x $400 \mathrm{mg} /$ hari dan etambutol 1 × $500 \mathrm{mg} /$ hari, selama 2 bulan pertama dan menunjukkan penyembuhan. Pasien dipantau lebih lanjut untuk masalah nutrisi dan perawatan pendek di poliklinik IKA RSCM. (Sari Pediatri 2010;12(2):108-15).
\end{abstract}

Kata kunci: Skrofuloderma, Mycobacterium tuberculosis, anak

\footnotetext{
Alamat korespondensi:

Dr. Darmawan B. Setyanto,.SpA (K). Divisi Respirologi Departemen Ilmu Kesehatan Anak FKUI-RSCM Jl. Salemba no.6 Jakarta 10430. Telepon 021-3148930 Fax.021-3148931.

Dr. johnny Nurman. (PPDS Dept. IKA FKUI) Email : johnnynurman@ yahoo.com
}

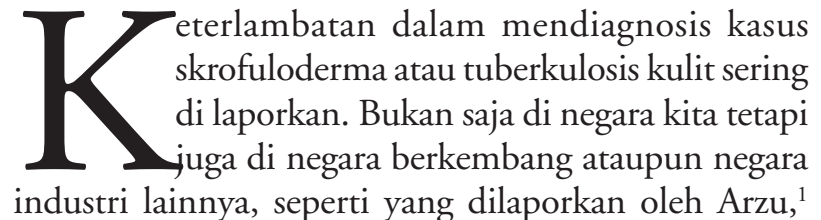
industri lainnya, seperti yang dilaporkan oleh Arzu, ${ }^{1}$ 
Sethuraman, ${ }^{2}$ dan Mlika dkk. ${ }^{3}$ Kasus skrofuloderma yang terlambat terdiagnosis dan terbengkalai sering mengakibatkan penyakit tersebut bertambah parah. Pengobatan yang tidak adequat, dan ketidakpatuhan pasien selama pengobatan dapat menyebabkan resistensi kuman tuberkulosis sehingga tidak memberikan respon yang baik terhadap pengobatan medikamentosa selanjutnya. Sebuah laporan kasus yang dialami oleh seorang anak perempuan, yang telah berobat selama $1 \frac{1 / 2}{2}$ tahun tanpa diagnosis dan pengobatan yang jelas. Hasil biopsi jaringan dan kelenjar getah bening sesuai dengan gambaran skrofuloderma tetapi pada pembiakan jaringan tidak ditemukan kuman Mycobacterium tuberculosis. Benarkah dia menderita tuberkulosis kulit?

\section{Kasus}

NDN, seorang anak perempuan, berusia 13 tahun 6 bulan, datang ke Poliklinik Umum Departemen Ilmu Kesehatan Anak Rumah Sakit Cipto Mangunkusumo (RSCM) Jakarta atas rujukan dari Poliklinik Bedah Anak RSCM pasca biopsi benjolan di leher dan ketiak kanan. Riwayat perjalanan penyakit dimulai dari empat tahun yang lalu, timbul benjolan di ketiak kanan sebesar kelereng, tidak nyeri, dan teraba kenyal. Benjolan semakin bertambah besar dalam kurun waktu satu tahun, menyebar ke dada dan leher kanan yang kemudian menjadi luka borok, sering mengeluarkan nanah dan terasa nyeri. Nafsu makan pasien menurun dan berat badan sulit naik, namun tidak disertai demam, batuk lama, batuk darah, dan sesak napas. Pasien pernah berobat sekitar dua tahun yang lalu, namun tidak mendapatkan penjelasan yang memuaskan akan penyakitnya. Pemeriksaan laboratorium dan pengangkatan tiga buah kelenjar getah bening di sekitar ketiak kanan dilakukan oleh dokter yang merawatnya. Setelah $1 \frac{1}{2}$ tahun pengobatan, tidak tampak membaik, bahkan benjolan di leher dan dagu bertambah besar.

Pasien dibawa berobat ke Poliklinik Bedah Anak RSCM dan dilakukan pengangkatan empat benjolan di dagu dan leher serta perawatan luka di ketiak dan dada kanan. Hasil pemeriksaan patologi memperlihatkan tuberkel dengan perkijuan dan sel datia Langhans, yang sesuai dengan gambaran limfadenitis tuberkulosis. Gambaran radiologis paru menunjukkan hasil infiltrat paru di perihilar bilateral dan adanya penebalan hilus. Pasien selanjutnya dirujuk ke Poliklinik Umum

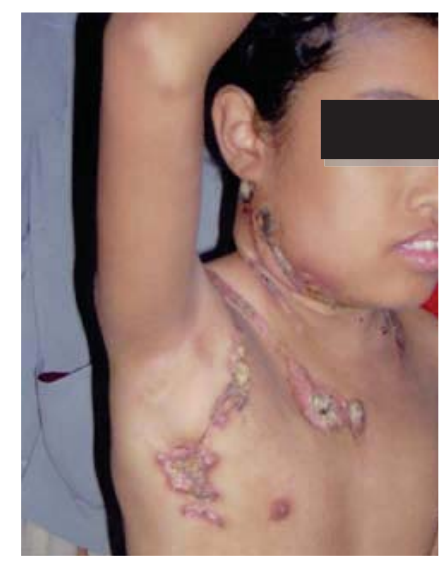

Gambar 1. Pasien sebelum berobat ke RSCM, tampak lesi basah tersebar dari regio colli, sub mandibula dextra dan sinistra menyebar secara linier ke dada dan axila dextra.

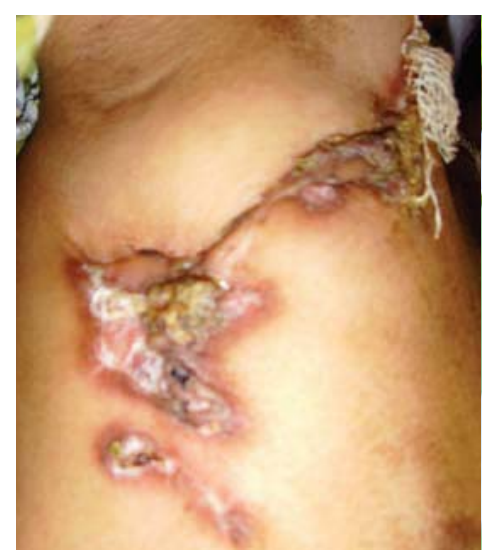

Gambar 2. Saat pasien berobat ke Poliklinik Dept. IKA, Div. Respirologi, RSCM. Tampak lesi pada dada dan axila dextra, yang sebagian telah dilakukan penjahitan oleh bagian Bedah RSCM.

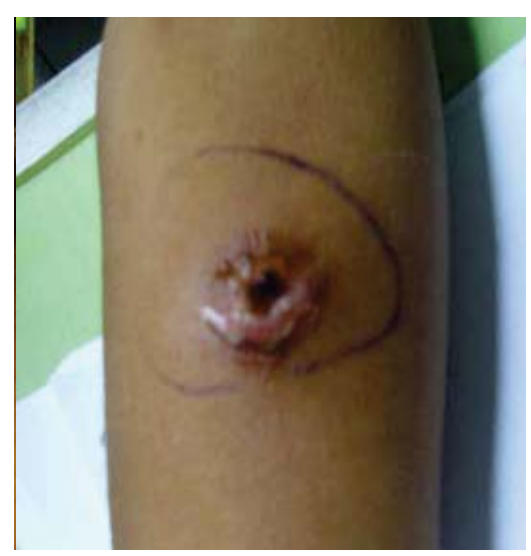

Gambar 3. Lengan kanan pasien dengan luka borok, 2 minggu setelah dilakukan uji Mantoux. 
Departemen IKA dan Klinik Divisi Respirologi untuk evaluasi serta tata laksana lebih lanjut. Riwayat tuberkulosis dalam keluarga disangkal dan tidak ada anggota keluarga yang menderita panyakit seperti pasien. Tetangga pasien diketahui menderita batuk berdarah. Pasien tinggal di lingkungan yang padat, dan kumuh dengan ventilasi yang kurang baik. Status imunisasi pasien tidak diketahui, namun terdapat jaringan parut BCG di lengan kanan atas. Kuantitas dan kualitas nutrisi pasien kesan kurang.

Pada pemeriksaan fisis pasien didapatkan dalam batas normal, kecuali berat badan dan tinggi badan berada pada < P3 (NCHS/CDC 2000) dengan kesan klinis gizi kurang dan perawakan pendek. Pada status dermatologi didapatkan benjolan sebesar telur puyuh, keras, tidak nyeri dan terfiksasi, serta lesi plak eritematosa dengan pinggir kebiruan dan hiperpigmentasi berukuran $1 \mathrm{x} 1 \mathrm{~cm}$ sampai $5 \mathrm{x} 10 \mathrm{~cm}$, bentuk tidak teratur, tersusun linier, berbatas tegas di servikalis, submandibula dekstra, klavicula dekstra dan sinistra, aksila dextra, dan sternum. Sebagian lesi tertutup krusta kering coklat tua-kekuningan, dan sebagian lesi tertutup kasa pasca eksisi (Gambar 1 dan 2). Kuku jari tangan tampak berwarna kuning kecoklatan dan mengeras dengan permukaan yang tidak merata. Status pubertas A1, P1, M2. Pemeriksaan bone age memberikan kesan retarded girl. Pemeriksaan rutin dan kimia darah menunjukkan adanya anemia ringan, sedangkan fungsi faal hati dan ginjal masih dalam batas normal.

Hasil uji Mantoux memperlihatkan bula berdiameter $>15 \mathrm{~mm}$, kemudian pecah dan menjadi lesi ulkus setelah 2 minggu (Gambar 3). Dilakukan biopsi kulit dan pemeriksaan patologi anatomi oleh Departemen Kulit dan Kelamin RSCM. Biopsi kulit memperlihatkan seluruh dermis dipadati oleh sel radang terutama limfosit, sel plasma PMN dan tampak sel epiteloid dan sel datia Langhans, juga ditemukan daerah yang granulomatus yang memberikan kesan sesuai dengan skrofuloderma. Biakan jaringan memperlihatkan Mycobacterium tuberculosis. Apusan sedian langsung tidak ditemukan kuman tahan asam, namun uji niasin memperlihatkan hasil positif. Hasil sensitifitas terhadap obat anti tuberkulosis (OAT) menunjukan kuman tersebut sensitif terhadap streptomicin, pirazinamid, isoniazid, rifampisin, dan etambutol.

Diagnosis kerja ditegakkan adalah skrofuloderma, gizi kurang, perawakan pendek karena penyakit kronis, anemia defisiensi besi, dan onikomikosis. Pasien mendapat terapi OAT oral dengan isoniazid 1 x $200 \mathrm{mg} /$ hari dan rifampisin 1 x $300 \mathrm{mg} /$ hari yang di rencanakan untuk 6 bulan, pirazinamid $1 \times 400 \mathrm{mg} /$ hari dan etambutol 1 × $500 \mathrm{mg} /$ hari, untuk 2 bulan pertama, serta vitamin B komplex.

\section{Pembahasan}

Tuberkulosis diperkirakan sudah ada sejak zaman purbakala, terbukti dengan ditemukan tanda penyakit tuberkulosis tulang pada vertebra manusia Neolitikum di Eropa (8000 tahun SM) dan mummi di Mesir (1000 tahun SM). Sejak era Hippokrates (400 tahun SM), tuberkulosis sudah dikenal sebagai penyakit yang menular. Tahun 1882 Robert Koch menemukan penyebab tuberkulosis yang dikenal sebagai Mycobacterium tuberculosis. ${ }^{4,5}$

Laporan surveillance 2009 yang dilakukan oleh Global Tuberculosis Control World Health Organization (WHO), pada tahun 2007 di Indonesia terdapat jumlah kejadian kasus baru pasien tuberkulosis 228/100.000 populasi/tahun dengan angka kematian sebesar 39/100.000 populasi per tahun, dari semua kasus tuberkulosis terdapat 22\% kasus yang merupakan multidrug resistant tuberculosis (MDRT). ${ }^{6}$

Tuberkulosis kulit merupakan bentuk tuberkulosis ekstrapulmonal yang sangat jarang dan bervariasi secara morfologi. Skrofuloderma adalah suatu bentuk dari tuberkulosis kulit, dan harus dipikirkan bila dijumpai lesi merah kebiruan, bengkak dan berbentuk luka borok. ${ }^{1,5}$ Salah satu penyebab tersering tuberkulosis kulit di Indonesia masih didominasi oleh Mycobacterium tuberculosis dan Mycobacterium atypical. Skrofuloderma merupakan bentuk tuberkulosis kulit yang tersering di temukan di RSCM (84\%), ${ }^{7}$ sedangkan Maulana Azad Medical College, India utara melaporkan hanya 36,9\% kasus skrofuloderma ditemukan. ${ }^{8}$ Medical College Kolkata, India selatan ${ }^{5}$ dan Research Institute for Tropical Disease, Philippines ${ }^{9}$ melaporkan masing-masing 21,1\% dan 20,4\% kasus skrofuloderma.

Kesalahan mendiagnosis skrofuloderma sering terjadi karena keterlambatan atau kelalaian diagnosis, selain daripada itu kesulitan untuk mendapat hasil biakan kuman tuberkulosis dan sebagian besar infeksi pada anak adalah pausibasiler sehingga diagnosis skrofuloderma sering diabaikan. ${ }^{1-3}$ Akibat dari kesalahan diagnosis dapat menyebabkan skrofuloderma 
tersebut menjadi semakin parah dan menyebar luas. Hal tersebut terlihat jelas pada laporan kasus ini, pasien telah berobat selama 1,5 tahun tanpa diagnosis dan pengobatan yang jelas.

Djuanda ${ }^{7}$ dan Rahajoe ${ }^{10}$ mengklasifikasikan tuberkulosis kulit berdasarkan morfologi kelainan kulit dan rute infeksi dari penyakit. Sedangkan Tappeiner, Klaus, ${ }^{11}$ mengklasifikasikan tuberkulosis kulit selain berdasarkan morfologi kelainan kulit dan cara penyebaran serta akibat vaksinasi BCG (Tabel 1), walaupun terdapat perbedaan dalam pengelompokan kelainan tersebut, namun pada dasarnya sama.

Skrofuloderma dikenal juga sebagai tuberculosis colliquativa cutis yang merupakan tuberkulosis subkutan yang kemudian membentuk abses dingin dan juga kerusakan sekunder terhadap kulit dipermukaannya. Skrofuloderma sering merupakan akibat keterlibatan kulit yang berdampingan dengan proses tuberkulosis lain yang sedang berlangsung, seperti pada daerah parotis, submandibular dan regio sub klavikula serta bagian lateral dari leher yang merupakan tempat predileksi tersering. Lesi dapat terjadi secara unilateral ataupun bilateral. Sedangkan lesi yang terjadi di ekstremitas dan badan bisanya disertai oleh tuberkulosis yang ada pada tulang jari tangan, sendi, sternum, dan tulang kosta. Skrofuloderma dapat mengenai semua golongan usia, meskipun golongan tersering adalah anak-anak, remaja, dan para lanjut usia. ${ }^{1,2,7-14}$

Lesi kulit awal berupa nodus subkutan keras, berbatas tegas, mudah digerakkan dari dasarnya tanpa disertai tanda infiltrasi. Dengan bertambah besar infiltrat, akan terjadi perlunakan. Diperlukan waktu berbulan-bulan hingga infiltrat tersebut menjadi cair dan kemudian pecah. Luka borok dan fistel akan terbentuk dan mengeluarkan cairan bening hingga purulen dan jaringan-jaringan kaseosa. Luka borok ini berbentuk garis lurus, mempunyai dasar granulasi dan tidak beraturan dengan tepi yang bergaung dan berwarna merah kebiruan. Terowongan dan celah penghubung tergali di bawah kulit dan menghubungkan antara jaringan subkutan dengan nodus yang sudah lunak. Penyembuhan lesi skrofuloderma yang membentuk jaringan parut memanjang dan tidak teratur, dapat terjadi spontan namun membutuhkan waktu yang lama. Kekambuhan dalam bentuk lesi tuberkulosis yang lain masih dapat terjadi pada jaringan parut tersebut. $^{7,8,10,15}$

Pemeriksaan penunjang pada tuberkulosis kulit secara umum meliputi pemeriksaan untuk penentuan tuberkulosis paru yang kemudian ditambah dengan pemeriksaan spesifik berupa biopsi lesi primer dengan cara aspirasi jarum halus (fine needle aspiration biopsy) ataupun secara biopsi terbuka (open biopsy). ${ }^{7,10,11}$ Pemeriksaan histopatologi skrofuloderma memberikan gambaran nekrosis yang masif dan berbentuk abses bagian tengah lesi yang tidak spesifik. Di bagian tepi abses atau sinus memperlihatkan tuberkuloid granuloma dan tuberkel (sel datia/sel epiteloid) yang sesungguhnya. Sel epiteloid menjadi komponen utama ditambah dengan sejumlah besar sel raksasa (giant cell). Mycobacterium tuberculosis dapat ditemukan dengan pewarnaan tahan asam (Zielh Neelsen).,11,15

Untuk menegakkan diagnosis tuberkulosis kulit berdasarkan hasil pemeriksaan laboratorium saja mungkin akan sulit. Pemeriksaan mikrobiologi secara langsung atau biakan sering negatif pada tuberkulosis

Tabel 1. Klasifikasi tuberkulosis kulit

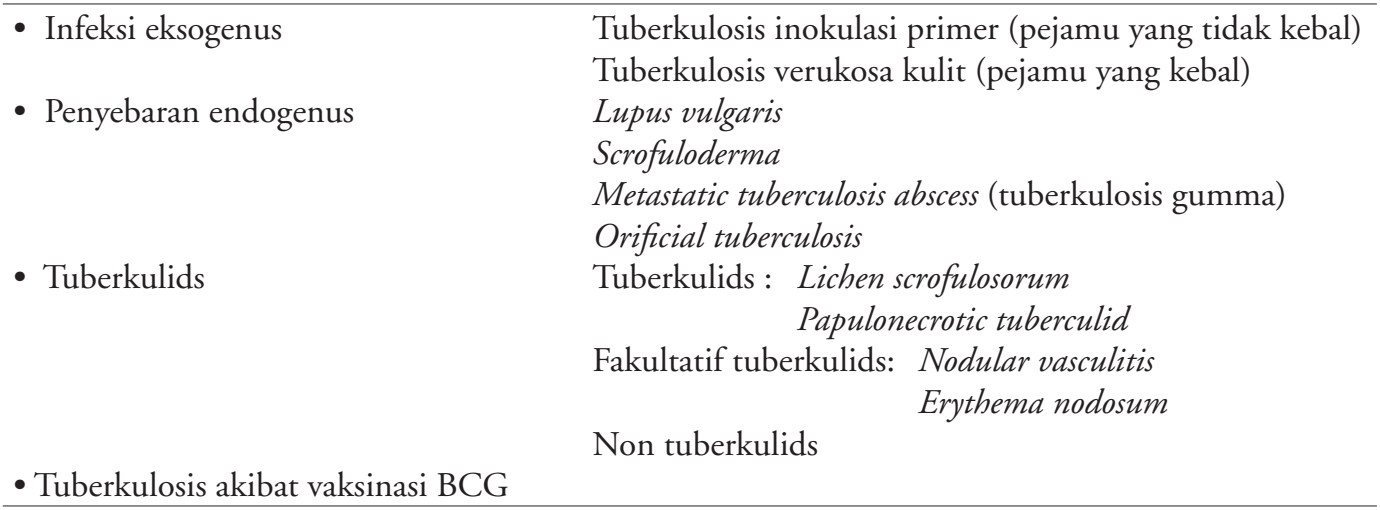

Tappeiner G, Klaus W. Tuberculosis and other mycobacterial infections. Dalam: Freedberg I, dkk., penyunting $7^{\text {th }}$. Fitzpatrick's dermatology in general medicine. USA: Mc Graw Hill, 2007.

Sari Pediatri, Vol. 12, No. 2, Agustus 2010 
Johnny Nurman dkk: Skrofuloderma pada anak: penyakit yang terlupakan?Laporan kasus

Tabel 2. Kriteria diagnosis tuberkulosis kulit

\begin{tabular}{ll}
\hline Diagnosis & Kriteria \\
\hline Absolut & Kultur, inokulasi pada marmot, PCR (spesimen berasal dari lesi kulit) \\
Relatif & - Anamnesis dan pemeriksaan fisik yang sesuai \\
& - Tuberkulosis pada organ dalam \\
& - Uji tuberkulin positif \\
& - Elisa positif terhadap antigen $M$. tuberculosis \\
& - Gambaran histopatologi yang sesuai dengan skrofuloderma \\
& - Ditemukan BTA pada spesimen dari lesi kulit \\
& - Respon terhadap pengobatan OAT \\
\hline
\end{tabular}

Steger JW, Barrett TL. Cutaneous tuberculosis ${ }^{15}$

kulit. Hal ini disebabkan infeksi tuberkulosis pada anak sering berbentuk pausibasiler sehingga pemeriksaan biakan dan hapusan basil tahan asam sering memberikan hasil negatif., ${ }^{7,11,12,16,17}$ Biopsi kelenjar pada laporan kasus memberikan gambaran khas tuberkulosis kulit, namun dengan adanya riwayat penggunaan obat yang tidak jelas dalam jangka waktu lama, maka biopsi jaringan lesi primer dan kultur dilakukan untuk memastikan tidak terjadi multi drug resistent therapy. Dalam mendiagnosis tuberkulosis kulit dapat menggunakan kriteria Steger ${ }^{15}$ diagnosis yang bersifat absolut atau relatif tergantung dari kriteria yang terpenuhi (Tabel 2), namun kriteria diagnosis tersebut juga memiliki kelemahan yakni diagnosis pasti hanya tergantung pada hasil biakan atau PCR positif, meskipun semua kriteria relatif terpenuhi. Pemeriksaan PCR dan biakan kuman mahal harganya, dan tidak selalu tersedia di semua institusi.

Biopsi kelenjar getah bening superfisial yang dilakukan di RSAB Harapan Kita pada 58 kasus tuberkulosis, hanya 16 pasien $(27,5 \%)$ yang memberikan hasil biopsi limfadenitis tuberkulosis. ${ }^{18}$ Pemeriksan histopatologi memberikan hasil yang khas, tetapi tidak patognomonik, karena penyakit granulomatosa lainnya seperti lepra, sarkoidosis, leismaniasis, dan infeksi jamur subkutan juga memberikan gambaran yang serupa. ${ }^{17}$

Pembiakan kuman Mycobacterium tuberculosis dapat menggunakan media Lowenstein-Jensen atau menggunakan sistim BACTEC Radiometric 460. Mycobacterium tuberculosis akan tumbuh dalam 3-4 minggu dengan media tersebut. Sebuah penelitian prospektif yang dilakukan oleh Aggarwal P dkk, ${ }^{16} 26$ mycobacterium berhasil diisolasi dari 35 pasien. Hanya 25,7\% hasil biakan positif pada media LowensteinJensen dengan rata-rata periode pertumbuhan 31,5 hari.
Sedangkan $62,8 \%$ dari spesimen yang telah diisolasi memberikan hasil positif dengan menggunakan sistim BACTEC, periode pertumbuhan kuman rata-rata dapat terjadi dalam 17,3 hari.

Menurut Gopinathan dkk, ${ }^{19}$ pada keadaan tertentu pertumbuhan kuman Mycobacterium tuberculosis hanya $50 \%$ yang memberikan hasil biakan positif, diduga karena sebagian kasus tuberkulosis kulit merupakan infeksi pausibasiler. Hasil biakan negatif, atau tidak ditemukannya kuman tahan asam pada pewarnaan Ziehl-Neelsen dan gambaran jaringan granuloma pada pemeriksaan histopatologi, tidak dapat menyingkirkan diagnosis skrofuloderma. ${ }^{20}$ Arya $\mathrm{dkk}^{21}$ menemukan apusan dengan pewarnaan Ziehl-Neelsen dan fluoresen serta kultur pada media Lowenstein-jensen negatif pada $95 \%$ kasus, meskipun terdapat hubungan antara manifestasi klinis dan histopatologi serta uji tuberkulin yang positif.

Sediaan langsung dengan pewarnaan Zielh Neelsen pada laporan kasus ini tidak memperlihatkan basil tahan asam. Mungkin disebabkan biakan Mycobacterium tuberculosis yang terisolasi sangat minimal atau pausibasiler, namun konfirmasi dengan tes niasin menunjukan hasil positif yang berarti adanya kuman Mycobacterium tuberculosis.

Skrofuloderma juga dapat disebabkan oleh Mycobacterium atypical yang merupakan kuman tahan asam, dengan sifat yang berbeda dibandingkan dengan Mycobacterium tuberculosis, patogenistasnya lebih rendah, membentuk pigmen pada pembiakkan dan dapat tumbuh pada suhu kamar. Infeksi Mycobacterium scrofulaceum pada kulit juga dapat menyerupai skrofuloderma dan sering menyebabkan limfadenitis pada anak usia 1-5 tahun. ${ }^{7,8,15}$

Skrofuloderma di daerah leher umumnya memiliki gambaran yang khas, sehingga mungkin tidak perlu 
dibandingkan dengan diagnosis lain. Jika lesi tersebut terdapat di daerah aksila maka hidraadenetis supurativa perlu di pertimbangkan. Hidraandenitis supurativa adalah penyakit yang bersifat akut yang disertai tanda-tanda radang akut yang jelas. Jika lesi di daerah inguinal, maka limfogranuloma venerum (LGV) dapat didiagnosis banding dengan skrofuloderma pada daerah tersebut. Perbedaan yang penting adalah pada riwayat LGV terdapat riwayat bersenggama disertai gejala konstitusi serta terdapat tanda radang akut, selain itu LGV menyerang KGB medial dan fosa iliaka, sedangkan skrofuloderma menyerang kelenjar getah bening inguinal lateral dan femoral. ${ }^{7,11}$

Tata laksana skrofuloderma pada anak harus komprehensif, meliputi terapi medikamentosa, tata laksana gizi, dan lingkungan sekitarnya. Terapi OAT pada skrofuloderma pada dasarnya sama dengan terapi tuberkulosis paru. ${ }^{7,9,10,14}$ Tujuan terapi medikamentosa tuberkulosis adalah memberikan penyembuhan yang lebih cepat, mencegah terjadinya resistensi dan kekambuhan. ${ }^{7,9,11,12}$ Keputusan pemberian medikamentosa dimulai segera setelah diagnosis skrofuloderma ditegakkan dengan dasar data epidemiologi, klinis pasien, uji tuberkulin, röngent thoraks dan hasil pemeriksaan histopatologi.

Terapi tuberkulosis terdiri dari dua tahap yakni tahap awal (intensif) dengan tujuan membunuh kuman yang aktif dengan obat yang bersifat bakterisidal, dan tahap lanjutan dengan tujuan untuk membunuh

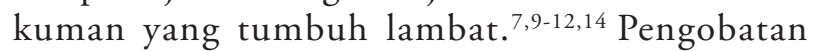
dengan komposisi 3 atau 4 regimen masih kontroversi. Menurut Djuanda A, ${ }^{7}$ pengobatan dengan regimen 3 OAT akan memberikan hasil yang memuaskan. ${ }^{10,15}$

Tabel 3. Obat anti tuberkulosis lini kedua

\begin{tabular}{ll}
\hline \multicolumn{1}{c}{ Obat } & \multicolumn{1}{c}{$\begin{array}{c}\text { Dosis harian } \\
(\text { dosis maksimum })\end{array}$} \\
\hline Capreomicin & $15-30 \mathrm{mg} / \mathrm{kg}(1 \mathrm{~g})$ \\
Kanamicin & $15-30 \mathrm{mg} / \mathrm{kg}(1 \mathrm{~g})$ \\
Etionamid & $15-20 \mathrm{mg} / \mathrm{kg}(1 \mathrm{~g})$ \\
Asam para-aminosalisilik (PAS) & $150 \mathrm{mg} / \mathrm{kg}(12 \mathrm{~g})$ \\
Cycloserin & $15-20 \mathrm{mg} / \mathrm{kg}(1 \mathrm{~g})$ \\
Ciprofloxasin & $500-1000 \mathrm{mg} / \mathrm{kg}$ \\
Ofloxasin & $400-800 \mathrm{mg} / \mathrm{hari}$ \\
Amikasin & $15 \mathrm{mg} / \mathrm{kg}$ \\
Clofazimin & $100-300 \mathrm{mg} / \mathrm{hari}$ \\
\hline
\end{tabular}

Handog EB, Gabriel TG, Trinidad RT. Management of Cutaneous Tuberculosis. Dermatologic Therapy 2008;21:154-1619
Sedangkan terapi dengan 4 OAT ditujukan untuk menghancurkan populasi Mycobacterium yang besar dengan cepat dan penyembuhan yang baik. . $^{-4,9,12,13}$ Etambutol dan streptomisin dapat diberikan apabila terdapat bukti yang menunjukan kuman resisten terhadap OAT. ${ }^{9,12,14}$

Kemungkinan resistensi terhadap OAT di negara berkembang sangat besar, maka penggunaan komposisi 4 OAT dapat dipertimbangkan. Seandainya terjadi resistensi kuman tuberkulosis pada suatu daerah, maka pengobatan OAT harus disesuaikan dengan pola resistensi kuman tuberkulosis yang ada di daerah atau negara tersebut, dan penggunaan OAT lini ke-2 dapat dipertimbangkan (Tabel 3). ${ }^{9}, 10,12,14$

Terapi OAT yang dipergunakan adalah isoniazid (5-15 mg/kg/hari), rifampisin (10-20 mg/kg/hari) dan pirazinamid (15-30 mg/kg/hari) pada 2 bulan pertama. Yang diikuti pemberian isoniazid dan rifampisin dengan dosis yang sama untuk 4 bulan berikutnya. Terapi OAT lainnya adalah etambutol $(15-25 \mathrm{mg} /$ $\mathrm{kg} /$ hari) dan streptomisin $(15-40 \mathrm{mg} / \mathrm{kg} /$ hari) untuk 2 bulan. Etambutol digunakan pada anak usia di atas 6 tahun dengan pertimbangan efek samping obat, digunakan pada saat anak yang ketajaman visual sudah dapat dinilai dan membedakan warna dengan jelas. Streptomisin lebih sering dipergunakan pada anak berusia kurang dari 6 tahun, penilaian terhadap pendengaran anak sudah dapat dinilai dengan baik. 2,3,9,12,14 Setelah diagnosis skrofuloderma ditegakkan terapi dengan regimen 4 OAT (isoniazid, rifampisin, pirazinamid dan etambutol) segera dimulai.

Perawatan luka yang telah dieksisi atau yang masih basah dianjurkan untuk dibersihkan saat mandi dan dioleskan dengan salep topikal. Pegobatan tuberkulosis kulit yang disebabkan oleh Mycobacterium atypical berbeda dengan Mycobacterium tuberculosis. Mycobacterium scrofulaceum tidak begitu sensitif terhadap OAT. Kombinasi antara obat antituberkulosis seperti isoniazid dengan dihidrostreptomisin atau klaritromisin dapat digunakan., ${ }^{7,911,14,16}$

Terapi selain dengan medikamentosa, obat topikal atau dengan pembedahan juga pernah dilaporkan. Terapi topikal dapat dilakukan dengan kompres air $\mathrm{NaCl} 0.9 \%$ serta perbaikan higiene. ${ }^{10}$ Intervensi pembedahan dengan melakukan eksisi, dapat mengurangi morbiditas dan mempersingkat lama pemberian OAT. ${ }^{11,12}$ Pencarian atau pengobatan terhadap tersangka sumber penularan di lingkungan perlu dilakukan. Cara hidup sehat dengan menjaga 


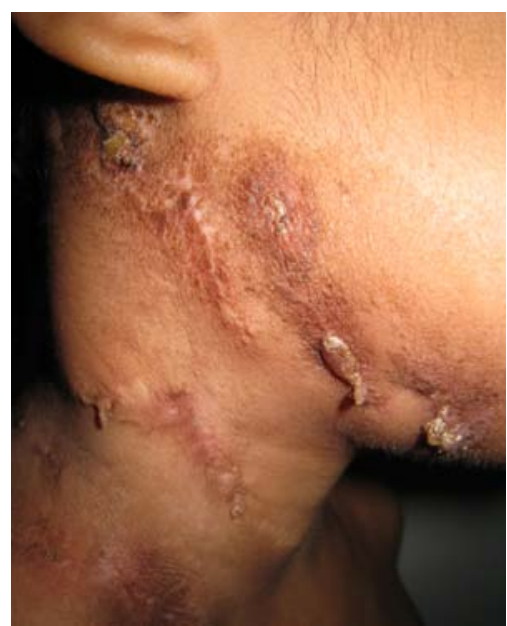

Gambar 4. Lesi yang menutup tampak di regio colli dextra dan submandibula dextra setelah 3 bulan pengobatan.

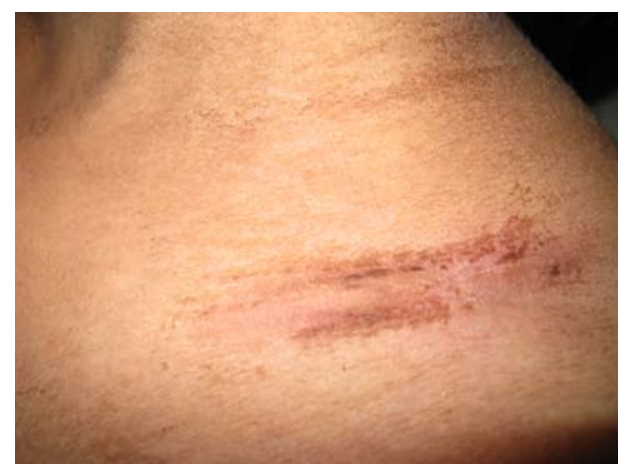

Gambar 5. Lesi di regio subclavicula sinistra yang hampir sembuh sempurna setelah 3 bulan pengobatan.

kebersihan diri dan lingkungan sangat dianjurkan, baik pada pasien maupun pada anggota keluarga. ${ }^{10}$ Mengingat keadaan nutrisi pasien yang kurang baik sebagai akibat penyakit kronis tersebut, maka konsultasi perencanaan dan pengaturan nutrisi sangat perlu untuk mencapai keberhasilan pengobatan yang optimal.

Kriteria penyembuhan pada skrofuloderma dapat dinilai dari fistel dan ulkus yang sudah menutup, sikatriks atau jaringan parut yang semula eritematosa menjadi berkurang atau hilang, serta seluruh kelenjar getah bening yang mengecil dengan ukuran kurang dari satu $\mathrm{cm}$ dengan konsistensi keras. ${ }^{7,11}$ Tanda tersebut terlihat jelas pada laporan pasien setelah menjalani pengobatan tiga bulan dengan empat macam OAT.
Prognosis skrofuloderma baik karena mortalitas sangat kecil bahkan hampir tidak ada, ${ }^{7,14}$ namun perlu didukung oleh ketaatan dan keteraturan pasien dalam mengikuti pengobatan OAT, serta memperbaiki higenitas lingkungan hidup. Pasien masih dalam masa pengobatan, apabila pasien tidak minum OAT secara teratur maka ke kambuhan dapat terjadi. Sumber infeksi dalam anggota keluarga harus diobati agar tidak memberikan infeksi berulang. Seluruh anggota keluarga telah disarankan untuk dilakukan pemeriksaan sputum, radiologi dada, dan uji tuberkulin.

\section{Daftar pustaka}

1. Arzu K, Ülker G, Secil S, Ilhan K, Levent A. Scrofuloderma: A forgetten disease? J SKIN med. 2007:303-4.

2. Sethuraman G, Kaur J, Nag HL, Khaitan BK, Sharma VK, Singh MK. Symmetrical scrofuloderma with tuberculosis verrucosa cutis. Clin Exp Dermatol. 2006;31:452-82.

3. Mlika RB, Tounsi J, Fenniche S, Hajlaoui K, Marrak H, Mokhtar I. Childhood cutaneous tuberculosis: a 20 years retrospective study in Tunis. Dermatol Online. 2006;12:11-3.

4. Monte SM, Carol AN. Cutaneous tuberculosis. medscape.com. 2010. Diunduh dari: http//www. eMedicine Specialties/Dermatology/Mycobacterium Infections emedicine. Diakses tanggal 27/4/2009.

5. Patra AC, Gharami RC, Banerjee PK. A profile of cutaneous tuberculosis. Indian J Dermato. 2009; 51:105-7.

6. WHO. Global tuberculosis control. WHO. Country profile Indonesia. 2009:113-6. Geneva, WHO.

7. Djuanda A. Tuberkulosis kutis. Dalam: Djuanda A, Hamzah M, Aisah S, penyunting. Ilme kesehatan kulit dan kelamin. Edisi ke-5. Jakarta: Fakultas kedokteran universitas indonesia; 2007. h.64-72.

8. Vashisht P, Sahoo B, Khurana N, Reddy BSN. Cutaneous tuberculosis in children and adolescence: a clinicohistological study. J Eur Acad Dermatol Venereol. 2007;21:40-7.

9. Handog EB, Gabriel TG, Trinidad RT. Management of cutaneous tuberculosis. Dermatol Ther. 2008;21:15461.

10. Rahajoe NN, Basir D, Makmuri MS, Kartasasmita CB. Diagnosis dan tatalaksana tuberkulosis ekstrapulmonal. Dalam: Unit kerja koordinasi respirologi, penyunting. 
Pedoman nasional tuberkulosis anak. Edisi ke-2. Jakarta: UKK Pulomonologi PPIDAI; 2008. h.13-72.

11. Tappeiner G, Klaus W. Tuberculosis and other mycobacterial infections. Dalam: Leffell DJ, Klaus W, Paller AS, Gilchrest BA, Stephen IK, Goldsmith LA, penyunting. Fitzpatrick's dermatology in general medicine. Edisi ke-7. New York, USA: McGraw-Hill; 2007. h.1768-86.

12. Lim-ong AL, Dizon MA, Carlos CC, Bunyi MAC, Yambao RG. Tuberculosis in infancy \& children. Dalam: Fong MF, penyunting. Handbook of childhood tuberculosis Philippine Pediatric Society. Edisi kePhilippines: PPS; 2003. h.10-80.

13. Mataix J, Botella R, Herrero A, Lucas A. Tuberculous primary complex of the skin. Int J Dermatol. 2008;47:479-81.

14. Munoz FM, Starke JR. Tuberculosis. Dalam: Behrman RE, Kliegmen RM, Jenson HB, Stanton BF, penyunting. Nelson textbook of pediatrics. Edisi ke-18. Philadelphia: WE Saunders; 2007. h.1240-62.

15. Steger JW, Barrett TL. Cutaneous tuberculosis. 2010. Diunduh dari: http//www.wramc.army.lib/ healthcarel med/derm/textbook/cutaneous/tb.pdf. Diakses tanggal 7/1/2009.
16. Aggarwal P, Singal A, Bhattacharya SN, Mishra K. Comparison of the radiometric BACTEC $460 \mathrm{~TB}$ culture system and Löwenstein-Jensen medium for the isolation of mycobacteria in cutaneous tuberculosis and their drug susceptibility pattern. Int J Dermatol. 2008;47:681-7.

17. Ramam M, Tejasvi T, Manchanda Y, Sharma S, Mittal $\mathrm{R}$. What is the appropiate duration a therapeutic trial in cutaneous tuberculosis? Further observation. Indian J Dermatol Venereol Leprol. 2007;73:243-6.

18. Widodo E. Tuberkulosis pada anak: diagnosis dan tata laksana. Dalam: Trihono PP, Prabosiri A, penyunting. Pediatrics update 2003. Edisi ke-Jakarta: Balai penerbit FKUI; 2003. h.67-76.

19. Gopinatahn R, Pandit D, Joshi J, Jerajani H, Mathur M. Clinical and morphological variants of cutaneous tuberculosis and its relation to mycobacterium species. Indian J Microbiol. 2001;19:193-6.

20. Raphael SS. Mycobacterium. Dalam: Raphael SS, penyunting. Medical laboratory technology. Edisi ke-4. New York: W.B Saunders; 1983. h.396-400.

21. Arya L, Koranne RV, Deb M. Cutaneous tuberculosis in children a clinico-microbiological study. Indian J Dermatol Venereol Leprol. 1999;65:137-9. 